\title{
The influence of non-steroidal anti-inflammatory drugs and paracetamol used for pain control of orthodontic tooth movement: a systematic review
}

\author{
ADRIANO S. CORRÊA ${ }^{1}$, VINÍCIUS L. DE ALMEIDA ${ }^{2}$, BEATRIZ M.V. LOPES ${ }^{1}$, ADEMIR FRANCO ${ }^{3}$, FELIPE \\ R. DE MATOS ${ }^{2}$, LUCINDO J. QUINTANS-JÚNIOR ${ }^{4}$, SIGMAR M. RODE ${ }^{5}$ and LUIZ R. PARANHOS ${ }^{2}$ \\ ${ }^{1}$ Programa de Biologia Oral, Centro de Ciências da Saúde, Universidade Sagrado \\ Coração, Rua Irmã Arminda, 10-50, 17011-160 Bauru, SP, Brazil \\ ${ }^{2}$ Departamento de Odontologia, Universidade Federal de Sergipe, Avenida \\ Governador Marcelo Déda, s/n, 49400-000 Lagarto, SE, Brazil \\ ${ }^{3}$ Departamento de Estomatologia, Universidade Federal do Paraná, Avenida \\ Lothário Meissner, 632, 80210-170 Curitiba, PR, Brazil \\ ${ }^{4}$ Departamento de Fisiologia, Universidade Federal de Sergipe, Avenida \\ Marechal Rondon, s/n, 49100-000 São Cristóvão, SE, Brazil \\ ${ }^{5}$ Departamento de Materiais Dentários e Prótese, Instituto de Ciência e Tecnologia, Universidade Estadual Júlio de \\ Mesquita Filho, Avenida Engenheiro Francisco José Longo, 777, 12201-970 São José dos Campos, SP, Brazil
}

Manuscript received on December 9, 2016; accepted for publication on January 30, 2017

\begin{abstract}
The present study aimed to perform a systematic literature review to determine if there is a non-steroidal anti-inflammatory drug (NSAID) that interferes less within tooth movement. This research was performed according to the PRISMA statement. Articles were searched in eight electronic databases (PubMed, Scopus, Embase, Web of Science, LILACS, SciELO, Google Scholar, and Open Grey). Only experimental studies on male Wistar rats were selected, which included experiments related to the influence of NSAIDs on orthodontic movement. Studies in animals with pathological conditions, literature review articles, letters to the editor and/or editorials, case reports, abstracts, books, and book chapters were excluded. Each of the steps of this systematic literature review was performed by two examiners independently. Results: the total sample consisted of 505 articles, from which 6 studies were eligible after a qualitative analysis. From the drugs assessed, paracetamol was unanimous for not interfering within orthodontic movement when compared to the control group. However, drugs such as aspirin, ibuprofen, sodium diclofenac, and selective cyclooxygenase- 2 inhibitors caused a reduction in tooth movement when compared to the control group. Conclusion: paracetamol could be considered the drug of choice for pain relief because it interferes less within tooth movement.
\end{abstract}

Key words: Anti-inflammatory, drug, orthodontics, non-steroidal, tooth movement.

Correspondence to: Luiz Renato Paranhos

E-mail: paranhos.lrp@gmail.com 


\section{INTRODUCTION}

Tooth movement is achieved through mechanical forces provided by orthodontic appliances. During the orthodontic treatment, a series of changes occur in periodontal tissues, such as the intense remodeling of the periodontal ligament (PDL) (Melsen 2015). In parallel, an essential inflammatory process occurs changing the local vascularization and increasing the blood flow in the PDL (Krishnan and Davidovitch 2006). Along with this process, cytokines, growth factors, transformation factors, and neurotransmitters are released (Bollen et al. 2008), creating a proper environment for bone remodeling. In this environment, bone resorption is observed on the compression side of the PDL fibers, while bone formation is observed on the tension side (Garlet et al. 2008).

More specifically, the expression of cytokines, such as tumor necrosis factor (TNF- $\alpha$ ) and interleukin 1- $\beta$ (IL1- $\beta$ ) (Garlet et al. 2007), occurs on the compression side, favoring inflammation. Thus, the inflammatory process may be associated with the recruitment of monocytes from the bloodstream by chemotaxis to the production site of these cytokines (Repeke et al. 2010, Goltzman and Hendy 2015). Monocytes would be stimulated by the receptor activator of nuclear factor $\mathrm{\kappa B}$ ligand (RANKL) to fuse and form giant cells similar to osteoclasts, culminating in higher bone resorption (Yamagushi 2009, Nakashima and Takayanagi 2009). However, tension forces stimulate synthesis and release of cytokines opposite to the inflammatory process, such as interleukin-10 (IL10) (Garlet et al. 2007). These mediators have a negative influence on the expression of TNF- $\alpha$ and IL1- $\beta$ and stimulate the synthesis of osteoprotegerin (OPG), which interferes with the differentiation of osteoclasts. Consequently, there is a higher bone deposition instead of resorption (Takayanagi 2012).

The synthesis/release of inflammatory mediators responsible for pain is also observed during tooth movement. These mediators have a clinical significance, once pain is often reported by patients undergoing orthodontic treatment (O'Connor 2000). In this context, non-steroidal anti-inflammatory drugs (NSAIDs) play an important part for pain control (Xiaoting et al. 2010). This type of drug is known as an inhibitor of the inflammatory network, including the cycle of arachidonic acid which results in the reduction of prostaglandins (De Carlos et al. 2006). However, these drugs also bring negative effects to the patients, e.g. the shortage of certain prostaglandins reduces the tooth displacement rate (Shetty et al. 2013).

Considering the current lack of scientific evidence towards the selection of drugs for pain control in orthodontic patients and the increasing need to achieve levels of excellence in orthodontic treatment, the present study aims to perform a systematic literature review to determine if there is a NSAID that interferes less within tooth movement.

\section{MATERIALS AND METHODS}

\section{PROTOCOL AND REGISTRATION}

This systematic review was performed according to the PRISMA checklist (Preferred Reporting Items for Systematic Reviews and Meta-Analyses) (Liberati et al. 2009) (www.prisma-statement.org).

No protocol record was found once this systematic literature review screened studies with animal samples. This type of study is not eligible for inclusion in the Prospective International Register of Systematic Reviews (PROSPERO).

\section{ELIGIBILITY CRITERIA}

Focused Question: The present systematic review was performed aiming to answer the following question: "Among non-steroidal anti-inflammatory drugs effective for pain control, is there one that interferes less within tooth movement?". The 
research question was based on the PICO strategy, where $\mathbf{P}$ (population) corresponds to the Wistar rats, I (intervention) corresponds to the NSAIDs used, $\mathbf{C}$ (comparison) corresponds to the comparison with a control group, and $\mathbf{O}$ (outcome) corresponds to the effect of drugs on orthodontic movement.

Inclusion criteria: Only experimental studies on male Wistar rats were selected, which should include experiments related to the influence of NSAIDs on orthodontic movement. Moreover, the studies should present quantitative and comparative measures regarding the initial and final status of induced tooth movement among groups of animals under or not NSAIDs. There was no restriction of publication time, status and language. It is important to note that NSAIDs not only consist of anti-inflammatory drugs, but also analgesics. The last has a primary analgesic and antipyretic function but weak anti-inflammatory potential, such as acetaminophen (paracetamol). It justifies why the acetaminophen is considered a NSAID by some authors (Karthi et al. 2012, Simmons et al. 2000) and was considered in the present study as well.

Exclusion criteria: Studies using animals with pathological conditions, literature review articles, letters to the editor and/or editorials, case reports, abstracts, books, and book chapters were excluded.

\section{INFORMATION SOURCES}

Searches were performed in the following databases: PubMed, Scopus, Embase, Web of Science, LILACS, SciELO, Google Scholar, and Open Grey. Google Scholar and Open Grey were used to search the "grey literature" and prevent any bias of article selection and publication. For Google Scholar, the first 100 results of the combination applied were used, excluding patents and citations.

\section{SEARCH}

The MeSH resource was used to select the descriptors "Non-steroidal", "Anti-inflammatory", and "Tooth Movement", linked by the Boolean operators "AND" and "OR". This research was performed in December, 2015.

The results obtained were exported to the software Mendeley Desktop 1.13.3 (Mendeley ${ }^{\mathrm{TM}}$ Ltd, London, UK), where duplicity was verified.

\section{STUDY SELECTION}

Data collection was performed at different times. Titles and abstracts were systematically analyzed based on eligibility by two examiners (A.S.C and V.L.A) blinded for the name of authors and journals. Whenever the title and abstract of articles did not present enough information, full texts were obtained and assessed. When the abstract was not available, full texts were assessed.

The full texts of the articles eligible previously were downloaded and read to verify the presence of every inclusion criteria. In specific cases, the authors of potentially eligible articles were contacted by e-mail and asked for the missing information. The rejected articles were registered separately, displaying the reasons for exclusion.

\section{DATA ITEMS}

After a complete screening, the texts of the articles selected were reassessed and the data was extracted standardly. The data extracted corresponded to the authorship, year of publication, study location, type of study, and other specific information such as quantity of male Wistar rats involved in the study (n), type of orthodontic appliance used, traction force applied, dental elements involved in the traction, drugs used, administration dose, and measure of orthodontic movement. Drugs that were different from NSAIDs were not considered at the moment of data extraction.

\section{RISK OF BIAS/QUALITY IN INDIVIDUAL STUDIES}

The quality of the methods used in the eligible articles was assessed by independent examiners, according to the PRISMA recommendation (Liberati et al. 2009). The assessment prioritized the 
clear description of information. At this point, the review was performed blindly, masking the names of authors and journals to avoid any potential bias and conflict of interests.

The authors assessed all the articles selected according to the score system proposed by Cericato et al. (2015) in order to judge the risk of bias individually for each article. Two authors classified the quality of the articles as "high" (score: 10 to 12 points), "moderate" (score: 6 to 9 points), "low" (score: 3 to 6 points), or "very low" (score: 0 to 3 points). In the lack of consensus regarding the quality, a third author intervened for the final decision.

\section{SUMMARY MEASURES}

Data synthesis was performed through a descriptive analysis of the articles selected, and the final product of the analysis was presented in narration/ dissertation form.

\section{PLANNED METHODS OF ANALYSIS}

A meta-analysis was planned depending on the homogeneity of the methods and data of the eligible articles. The assessment of the risk of bias was also planned depending on the feasibility of the metaanalysis.

\section{RESULTS}

\section{STUDY SELECTION}

The search performed in eight electronic databases resulted in a sample of 280 articles, from which 33 were detected in PubMed database, 40 in Scopus, 95 in Embase, 9 in Web of Science, 100 in Google Scholar, and 3 in LILACS. No article was detected in SciELO and Open Grey databases. After the initial screening, 74 duplicates were eliminated, remaining 206 articles for the systematic reading of titles and abstracts. At this stage 122 articles were excluded for having no direct relation to the main topic of the present research. Other 74 articles were excluded because they were 58 literature reviews, 12 case reports, and 4 experiments performed with other animal species. The full texts of the 10 remaining articles were obtained and analyzed. After this step, 4 articles were excluded for not expressing quantitative measures of orthodontic traction in the control group and experimental groups. Finally, only 6 articles were selected for the present review.

A manual search in the reference lists of the eligible articles was performed to assess the quality of the search strategy. Two-hundred and twenty five references were separated for analysis (from the 6 eligible articles). Sixty duplicates were excluded. The 165 remaining articles underwent systematic reading of titles and abstracts, from which 120 were excluded for having no direct relation to the main topic of the present research. Other 38 articles corresponding to literature reviews were excluded, as well as 7 articles that used other animal species. Based on that, no article was included after the manual search confirming the effectiveness of the initial search strategy. The Prisma flowchart illustrates the selection scheme (Figure 1).

\section{STUDY CHARACTERISTICS}

From the 6 eligible articles, one was performed in Mexico (Arias and Marquez-Orozco 2006), two in Spain (De Carlos et al. 2006, 2007), two in Brazil (Hauber Gameiro et al. 2008, Stabile et al. 2009), and one in Japan (Gonzales et al. 2009). These publications dated between 2006 and 2009. All these articles commented on the ethical criteria involved in the experimental research. The summary of articles and interventions is shown in Table I.

\section{RISK OF BIAS/QUALITY IN INDIVIDUAL STUDIES}

The studies were relatively heterogeneous and none of them complied with all the method criteria of individual quality. However, one study (Stabile et 


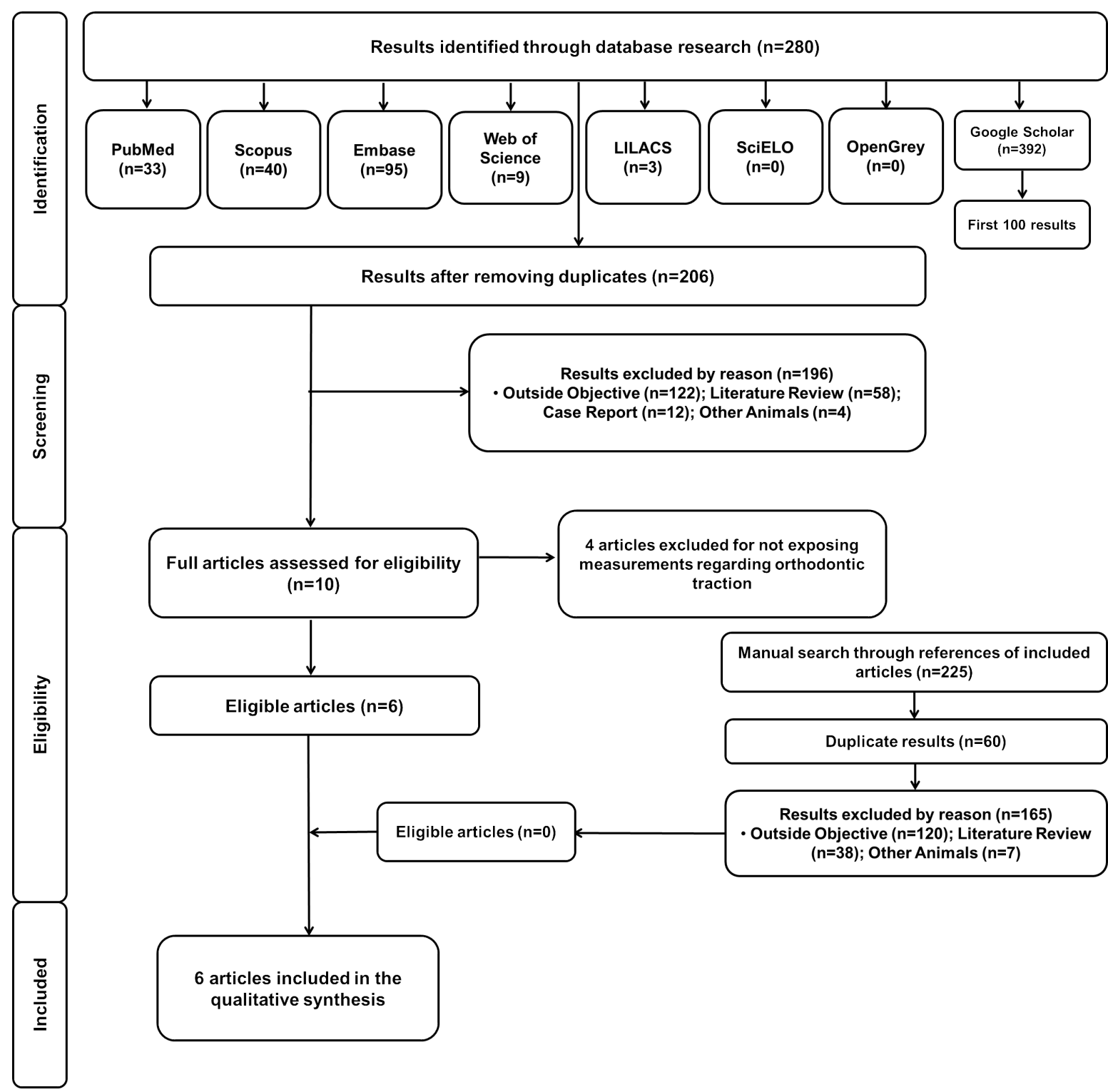

Figure 1 - Flow diagram of the strategies used for identification, screening, and inclusion of studies in the systematic review - adapted from PRISMA.

al. 2009) presented high individual quality. Table II shows the scores and criteria used for the analysis of risk of bias and individual quality of the eligible articles.

\section{SYNTHESIS OF RESULTS AND RISK OF BIAS ACROSS STUDIES}

Table I shows that there was heterogeneity regarding the type of orthodontic appliance used, anatomic region of installation, and teeth involved.
Two articles analyzed the effects of NSAIDs on interincisal gap (Arias and Marques-Orozco 2006, Stabile et al. 2009), while 4 verified the action of NSAIDs on traction of the first maxillary molar (De Carlos et al. 2006, 2007, Hauber Gameiro et al. 2008, Gonzales et al. 2009).

Tables III and IV also show differences regarding the type of drug used, concentration, form, and respective administration period. The NSAIDs involved were aspirin, paracetamol, 
TABLE I

Interventions used to assess the influence of NSAIDs on orthodontic movement according to PICO strategy.

\begin{tabular}{llllll}
\hline & $\mathrm{P}$ & $\mathrm{I}$ & & \\
\cline { 3 - 5 } Studies & Animals & Orthodontic Mechanotherapy & TT & Dose & O
\end{tabular}

molar and the central incisor, orthodontic De Carlos 42 male force of $50 \mathrm{~g}$ was used for the first half of et al. 2006 Wistar rats the sample, and orthodontic force of $100 \mathrm{~g}$ was used for the other half. Drugs used: rofecoxib and diclofenac. Control group: saline solution.

Orthodontic appliance 3-pin loop, 2-mm diameter, 12-mm long arms, "V" folds, placed at $9 \mathrm{~mm}$ from the coil region, made

Arias and

Marquez-

Orozco

2006

De Carlos 28 male

et al. 2007 Wistar rats

Hauber

Gameiro et 32 male al. 2008

Stabile et al. 2009

Gonzales et al. 2009

45 male Wistar rats 15 male Wistar rats from 0.016 beta-titanium alloy wire, imposing force of $35 \mathrm{~g}$ between lower incisors. Drugs used: aspirin, ibuprofen, and paracetamol. Control group: water filtered by reverse osmosis.

Through closed unilateral helical spring, connected between the first left maxillary molar and the central incisor, orthodontic force of $50 \mathrm{~g}$ was used. Drugs used: rofecoxib, celecoxib, and parecoxib. Control group: saline solution.

Through closed Nickel-Titanium helical spring, connected between the first maxillary molar and the central incisor, orthodontic force of $50 \mathrm{~g}$ was used. Drugs used: celecoxib. Control group: saline solution.

Fixed orthodontic appliance made of a 0.016 stainless steel torsion spring, with each edge welded to 0.004 " $\mathrm{x} 0.06$ " stainless steel rings (bands), imposing

force of $30 \mathrm{~g}$ between upper incisors. Drugs used: celecoxib, paracetamol. Control Group: $\quad 0.4 \%$ carboxymethylcellulose solution.

Through closed Nickel-Titanium helical spring, connected between the first left maxillary molar and the central incisor, an orthodontic force of $50 \mathrm{~g}$ was used. Drugs used: aspirin, paracetamol, meloxicam, and celecoxib. Control group: no drugs.

$\begin{array}{lc}10 & \text { Rofecoxib }-2 \mathrm{mg} / \mathrm{Kg} \\ \text { days } & \text { Diclofenac }-10 \mathrm{mg} / \mathrm{Kg} \\ & 0.9 \% \text { saline solution }\end{array}$

$0.9 \%$ saline solution

$$
\begin{aligned}
& \text { Aspirin - } 100 \mathrm{mg} / \mathrm{Kg} \\
& \text { Ibuprofen - 30mg/Kg }
\end{aligned}
$$$$
\text { Paracetamol - 200mg/Kg }
$$

\section{Rofecoxib - 0.5mg/Kg}

Celecoxib - $8 \mathrm{mg} / \mathrm{Kg}$

Parecoxib - 25mg/Kg

$0.9 \%$ saline solution

Celecoxib - 10mg/Kg saline solution

2
days

Celecoxib - 50mg/Kg

Paracetamol - 200mg/Kg

$0.4 \%$ carboxymethylcellulose
Aspirin - 300mg/Kg and $60 \mathrm{mg} / \mathrm{Kg}$

14 Paracetamol $-100 \mathrm{mg} / \mathrm{Kg}$ and $20 \mathrm{mg} / \mathrm{Kg}$

days Celecoxib $-16 \mathrm{mg} / \mathrm{Kg}$ and $3.2 \mathrm{mg} / \mathrm{Kg}$

Meloxicam $-13 \mathrm{mg} / \mathrm{Kg}$ and $67 \mathrm{mg} / \mathrm{Kg}$

P: population; I: intervention; C comparison; O: outcomes; TT: time of treatment; $\sqrt{ }$ : comparison with control group and outcomes performed and reported in the study, respectively. 
TABLE II

Assessment of risk of bias and individual quality of eligible articles. Scores and criteria used as proposed by Cericato et al. 2015.

\begin{tabular}{|c|c|c|c|c|c|c|c|c|c|c|}
\hline Authors & $\begin{array}{c}\text { Q.1 } \\
\text { (1 point) }\end{array}$ & $\begin{array}{c}\text { Q.2 } \\
\text { (1 point) }\end{array}$ & $\begin{array}{c}\text { Q.3 } \\
\text { (3 points) }\end{array}$ & $\begin{array}{c}\text { Q.4 } \\
\text { (1 point) }\end{array}$ & $\begin{array}{c}\text { Q.5 } \\
\text { (2 points) }\end{array}$ & $\begin{array}{c}\text { Q.6 } \\
\text { (2 points) }\end{array}$ & $\begin{array}{c}\text { Q.7 } \\
\text { (1 point) }\end{array}$ & $\begin{array}{c}\text { Q.8 } \\
\text { (1 point) }\end{array}$ & Total & $\begin{array}{c}\text { General } \\
\text { quality }\end{array}$ \\
\hline $\begin{array}{l}\text { De Carlos et } \\
\text { al. } 2006\end{array}$ & $\sqrt{ }$ & $\sqrt{ }$ & $\sqrt{ }(1$ point $)$ & $\sqrt{ }$ & -- & $\sqrt{ }$ & $\sqrt{ }$ & $\sqrt{ }$ & 8 points & ++ \\
\hline $\begin{array}{c}\text { Arias and } \\
\text { Marquez- } \\
\text { Orozco } 2006\end{array}$ & $\sqrt{ }$ & $\sqrt{ }$ & $\sqrt{ }(2$ points $)$ & $\sqrt{ }$ & -- & $\sqrt{ }$ & $\sqrt{ }$ & $\sqrt{ }$ & 9 points & ++ \\
\hline $\begin{array}{c}\text { De Carlos et } \\
\text { al. } 2007\end{array}$ & $\sqrt{ }$ & $\sqrt{ }$ & $\sqrt{ }(2$ points $)$ & $\sqrt{ }$ & -- & $\sqrt{ }$ & $\sqrt{ }$ & $\sqrt{ }$ & 9 points & ++ \\
\hline $\begin{array}{c}\text { Hauber } \\
\text { Gameiro et al. } \\
2008\end{array}$ & $\sqrt{ }$ & $\sqrt{ }$ & $\sqrt{ }(2$ points $)$ & $\sqrt{ }$ & -- & $\sqrt{ }$ & $\sqrt{ }$ & $\sqrt{ }$ & 9 points & ++ \\
\hline $\begin{array}{c}\text { Stabile et al. } \\
2009\end{array}$ & $\sqrt{ }$ & $\sqrt{ }$ & $\sqrt{ }(2$ points $)$ & $\sqrt{ }$ & $\sqrt{ }$ & $\sqrt{ }$ & $\sqrt{ }$ & $\sqrt{ }$ & $\begin{array}{c}11 \\
\text { points }\end{array}$ & +++ \\
\hline $\begin{array}{l}\text { Gonzales et } \\
\text { al. } 2009\end{array}$ & $\sqrt{ }$ & $\sqrt{ }$ & $\sqrt{ }(2$ points $)$ & $\sqrt{ }$ & -- & $\sqrt{ }$ & $\sqrt{ }$ & $\sqrt{ }$ & 9 points & ++ \\
\hline
\end{tabular}

Q.1 - abstract presents research objectives, methodology, results, and conclusion. Q.2 - ethical aspects are reported. Q.3 - adequate study design (information on the type of study, inclusion and exclusion criteria, and randomization). Q.4 - presence of control group. Q.5 - definition of sample size is described. Q.6 - statistical method is reported, including p value. Q.7 - research objective and results are clearly reported. Q.8 - research limitations are reported. V: yes; --: no. General quality: moderate $(++)$; high $(+++)$.

TABLE III

Influence of drugs on orthodontic movement when assessing the separation between central incisors.

\begin{tabular}{|c|c|c|c|}
\hline Drugs Used & Studies & Sample division by drugs and concentrations used & $\begin{array}{l}\text { Measurement of tooth } \\
\text { movement }(\mathrm{mm})\end{array}$ \\
\hline \multirow{2}{*}{ aspirin } & \multirow{2}{*}{$\begin{array}{l}\text { Arias and Marquez- } \\
\text { Orozco } 2006\end{array}$} & E.G.: 9 rats $-100 \mathrm{mg} / \mathrm{Kg}$ & $1.77 \pm 0.44$ \\
\hline & & C.G.: 9 rats $-0.6 \mathrm{ml}$ of water filtered by reverse osmosis & $2.89 \pm 0.99$ \\
\hline \multirow{2}{*}{ ibuprofen } & \multirow{2}{*}{$\begin{array}{l}\text { Arias and Marquez- } \\
\text { Orozco } 2006\end{array}$} & E.G.: 9 rats $-30 \mathrm{mg} / \mathrm{Kg}$ & $1.69 \pm 0.33$ \\
\hline & & C.G.: 9 rats $-0.6 \mathrm{ml}$ of water filtered by reverse osmosis & $2.89 \pm 0.99$ \\
\hline \multirow{4}{*}{ paracetamol } & \multirow{2}{*}{$\begin{array}{l}\text { Arias and Marquez- } \\
\text { Orozco } 2006\end{array}$} & E.G.: 9 rats $-200 \mathrm{mg} / \mathrm{Kg}$ & $2.49 \pm 0.39$ \\
\hline & & C.G.: 9 rats $-0.6 \mathrm{ml}$ of water filtered by reverse osmosis & $2.89 \pm 0.99$ \\
\hline & \multirow{2}{*}{ Stabile et al. 2009} & E.G.: 5 rats $-200 \mathrm{mg} / \mathrm{Kg}$ & $1.22 \pm 0.04$ \\
\hline & & C.G.: 5 rats $-1 \mathrm{ml}$ of $0.4 \%$ carboxymethylcellulose solution & $1.11 \pm 0.03$ \\
\hline \multirow{2}{*}{ celecoxib } & \multirow{2}{*}{ Stabile et al. 2009} & E.G.: 5 rats $-50 \mathrm{mg} / \mathrm{Kg}$ & $1.11 \pm 0.05$ \\
\hline & & C.G.: 5 rats $-1 \mathrm{ml}$ of $0.4 \%$ carboxymethylcellulose solution & $1.11 \pm 0.03$ \\
\hline
\end{tabular}

E.G.: experimental Group; C.G.: control group. 
TABLE IV

Influence of NSAIDs on orthodontic movement when assessing traction of the first maxillary molar.

\begin{tabular}{|c|c|c|c|}
\hline Drugs Used & Studies & Sample division by drugs and concentrations used & $\begin{array}{l}\text { Measurement of } \\
\text { tooth movement } \\
\qquad(\mathrm{mm})\end{array}$ \\
\hline \multirow{3}{*}{ Aspirin } & \multirow{3}{*}{$\begin{array}{l}\text { Gonzales et } \\
\text { al. } 2009\end{array}$} & E.G.1: 5 rats $-300 \mathrm{mg} / \mathrm{Kg}$ & $0.24 \pm 0.02$ \\
\hline & & E.G.2: 5 rats $-60 \mathrm{mg} / \mathrm{Kg}$ & $0.28 \pm 0.03$ \\
\hline & & C.G.: 5 rats - no drugs & $0.28 \pm 0.02$ \\
\hline \multirow{3}{*}{ Meloxicam } & \multirow{3}{*}{$\begin{array}{l}\text { Gonzales et } \\
\text { al. } 2009\end{array}$} & E.G.1: 5 rats $-67 \mathrm{mg} / \mathrm{Kg}$ & $0.25 \pm 0.01$ \\
\hline & & E.G.2: 5 rats $-13 \mathrm{mg} / \mathrm{Kg}$ & $0.26 \pm 0.01$ \\
\hline & & C.G.: 5 rats - no drugs & $0.28 \pm 0.02$ \\
\hline \multirow{3}{*}{ Paracetamol } & \multirow{3}{*}{$\begin{array}{l}\text { Gonzales et } \\
\text { al. } 2009\end{array}$} & E.G.1: 5 rats $-100 \mathrm{mg} / \mathrm{Kg}$ & $0.25 \pm 0.04$ \\
\hline & & E.G.2: 5 rats $-20 \mathrm{mg} / \mathrm{Kg}$ & $0.27 \pm 0.01$ \\
\hline & & C.G.: 5 rats - no drugs & $0.28 \pm 0.02$ \\
\hline \multirow{9}{*}{ Celecoxib } & \multirow{2}{*}{$\begin{array}{l}\text { De Carlos et } \\
\text { al. } 2007\end{array}$} & E.G.: 6 rats $-8 \mathrm{mg} / \mathrm{Kg}$ & $0.22 \pm 0.04$ \\
\hline & & C.G.: 12 rats - saline solution & $0.33 \pm 0.07$ \\
\hline & \multirow{4}{*}{$\begin{array}{l}\text { Hauber } \\
\text { Gameiro et } \\
\text { al. } 2008\end{array}$} & E.G.1: 9 rats $-10 \mathrm{mg} / \mathrm{Kg}$ for 3 days & $0.15 \pm 0.06$ \\
\hline & & C.G.1: 9 rats - saline solution for 3 days & $0.28 \pm 0.05$ \\
\hline & & E.G.2: 7 rats $-10 \mathrm{mg} / \mathrm{Kg}$ for 14 days & $0.23 \pm 0.07$ \\
\hline & & C.G.2: 7 rats - saline solution for 14 days & $0.33 \pm 0.12$ \\
\hline & \multirow{3}{*}{$\begin{array}{l}\text { Gonzales et } \\
\text { al. } 2009\end{array}$} & E.G.1: 5 rats $-16 \mathrm{mg} / \mathrm{Kg}$ & $0.16 \pm 0.02$ \\
\hline & & E.G.2: 5 rats $-3.2 \mathrm{mg} / \mathrm{Kg}$ & $0.20 \pm 0.02$ \\
\hline & & C.G.: 5 rats - no drugs & $0.28 \pm 0.02$ \\
\hline \multirow{6}{*}{ Rofecoxib } & \multirow{4}{*}{$\begin{array}{l}\text { De Carlos et } \\
\text { al. } 2006\end{array}$} & E.G.1: 7 rats $-2 \mathrm{mg} / \mathrm{Kg}$ (group under orthodontic force of $50 \mathrm{~g}$ ) & No movement \\
\hline & & C.G.1: 7 rats - $0.9 \%$ saline solution (group under orthodontic force of $50 \mathrm{~g}$ ) & $0.43 \pm 0.13$ \\
\hline & & E.G.2: 7 rats $-2 \mathrm{mg} / \mathrm{Kg}$ (group under orthodontic force of $100 \mathrm{~g}$ ) & $0.19 \pm 0.13$ \\
\hline & & C.G.2: 7 rats - saline solution (group under orthodontic force of $100 \mathrm{~g}$ ) & $0.72 \pm 0.14$ \\
\hline & \multirow{2}{*}{$\begin{array}{l}\text { De Carlos et } \\
\text { al. } 2007\end{array}$} & E.G.: 5 rats $-0.5 \mathrm{mg} / \mathrm{Kg}$ & No movement \\
\hline & & C.G.: 12 rats - saline solution & $0.33 \pm 0.07$ \\
\hline \multirow{2}{*}{ Parecoxib } & \multirow{2}{*}{$\begin{array}{l}\text { De Carlos et } \\
\text { al. } 2007\end{array}$} & E.G.: 5 rats $-25 \mathrm{mg} / \mathrm{Kg}$ & $0.42 \pm 0.09$ \\
\hline & & C.G.: 12 rats - saline solution & $0.33 \pm 0.07$ \\
\hline \multirow{4}{*}{$\begin{array}{l}\text { Sodium } \\
\text { diclofenac }\end{array}$} & \multirow{4}{*}{$\begin{array}{l}\text { De Carlos et } \\
\text { al. } 2006\end{array}$} & E.G.1: 7 rats $-10 \mathrm{mg} / \mathrm{Kg}$ (group under orthodontic force of $50 \mathrm{~g}$ ) & No movement \\
\hline & & C.G.1: 7 rats - saline solution (group under orthodontic force of $50 \mathrm{~g}$ ) & $0.43 \pm 0.13$ \\
\hline & & E.G.2: 7 rats $-10 \mathrm{mg} / \mathrm{Kg}$ (group under orthodontic force of $100 \mathrm{~g}$ ) & No movement \\
\hline & & C.G.2: 7 rats - saline solution (group under orthodontic force of $100 \mathrm{~g}$ ) & $0.72 \pm 0.14$ \\
\hline
\end{tabular}

E.G.: experimental group; C.G.: control group. 
meloxicam, diclofenac, ibuprofen, celecoxib, rofecoxib, and parecoxib.

The articles selected for this analysis were considered heterogeneous not allowing a metaanalysis.

\section{DISCUSSION}

Tooth movement induced by orthodontic treatment may cause pain (Krishnan and Davidovitch 2006). Algesia begins after installing the orthodontic appliance, peaking at around 24 hours and returning to basal levels in the course of seven days (Scheurer et al. 1996, Fernandes et al. 1998). Low level laser therapy (Limpanichkul et al. 2006), transcutaneous electrical nerve stimulation (Weiss and Carver 1994), and vibratory stimulation of the periodontal ligament (Marie et al. 2003) are some of the many therapies for pain control, but the administration of NSAIDs is the most used alternative for controlling algesia during orthodontic treatment (Krishnan and Davidovitch 2006).

It is known that macrophages and neutrophils release several cytokines, such as VEGF, TGF- $\alpha$, TGF- $\beta 1$, TNF- $\alpha$, and IL- $1 \beta$, and that they effectively participate in the inflammatory process and bone resorption (Garlet et al. 2008). The use of drugs that reduce or inhibit the production of these proteins may interfere with bone remodeling, and therefore, with orthodontic movement (Shetty et al. 2013). The NSAIDs are found among these drugs that work by inhibiting cyclooxygenase, which is the enzyme responsible for modulating the synthesis of prostaglandins during the arachidonic acid cycle (De Carlos et al. 2006). Among several types of prostaglandins, E2 is the one that increases vasodilatation the most, increasing also the vascular permeability and participating in the mechanism of osteoclastic activation and bone resorption (Sari et al. 2004). Researches show that this mediator is also responsible for increased tooth movement (Seifi et al. 2003, Kale et al. 2004). Thus, the use of certain NSAIDs may cause a reduction in this movement rate (Shetty et al. 2013).

Despite the delay of tooth movement caused by NSAIDs (Arias and Marques-Orozco 2006), paracetamol does not seem to interfere with the synthesis of prostaglandins and the course of orthodontic treatment (Shetty et al. 2013). However, there is still no precise recommendation regarding the most adequate drug for pain control in orthodontic treatment. In this context, determining the NSAID that reduces algesia the most without influencing on tooth displacement becomes essential to optimize the orthodontic treatment.

Studies performed with aspirin showed no similar outcomes (Arias and Marques-Orozco 2006, Gonzales et al. 2009). In the study performed by Arias et al. (Arias and Marques-Orozco 2006) there was a statistically significant difference in favor of the control group, while this drug had considerably less influence on tooth displacement in the study by Gonzales et al. (2009). Both studies were also different regarding the experimental period, type of orthodontic appliance used, anatomic region of appliance installation, orthodontic force applied, teeth involved, and drug concentration used. Perhaps the trabecular bone density in the posterior region of the maxilla; the more intense force applied by the orthodontic appliance; and especially the experimental period overcame the negative effect of aspirin on tooth movement in the study by Gonzales et al. (2009). Specifically, in relation to the experimental period is known that acute inflammatory reaction peaks after 24 to 48 hours after installing the orthodontic appliance and reduces intensity in the course of seven days (Limpanichkul et al. 2006). In this study, an experimental period of 14 days was used.

Ibuprofen is a drug used only in the study by Arias and Marquez-Orozco (2006), showing significant influence in reducing tooth movement. According to the authors (Arias and MarquesOrozco 2006), this occurrence may be linked to the 
intense effect of this anti-inflammatory regarding the inhibition of prostaglandins synthesis. Yet the prostaglandins are present during the mechanism of osteoclastic activation and bone resorption induction (Repeke et al. 2010). Consequently, a lower quantity of osteoclasts was verified along the area under forces of orthodontic compression, when compared to the control group (Arias and Marquez-Orozco 2006). Other authors confirm the prostaglandins as mediators related to the increase in tooth movement (Goltzman and Hendy 2015, Yamaguchi 2009) - as observed by Yamasaki et al. (1984), who achieved an increased canine tooth displacement after introducing prostaglandins along the region under forces of orthodontic compression.

Sodium diclofenac is a drug used only in the study by De Carlos et al. (2006), having strong influence on tooth movement. This drug completely inhibited the orthodontic movement of the first maxillary molar in experimental groups under forces of $50 \mathrm{~g}$ and $100 \mathrm{~g}$. According to the authors (De Carlos et al.2006), this aspect confirms the idea of the existing relation among products originated from cyclooxygenase enzymes on arachidonic acid, such as prostaglandins, and potential influence on bone modeling in favor of tooth movement (Goltzman and Hendy 2015). On the other hand, the literature also affirms that tooth movement is not only influenced by NSAIDs but also by the intensity of orthodontic force used (Alhashimi et al. 2001, Kanzaki et al. 2002). It may be proved by differences in tooth movement between control groups under orthodontic forces of $50 \mathrm{~g}$ and $100 \mathrm{~g}$ (De Carlos et al.2006). In relation to pain control, sodium diclofenac revealed effectiveness as an anti-inflammatory non-selective COX-1 and COX2 , overlapping the effect of intensity of orthodontic forces and inhibiting tooth displacement during the entire experimental period of the study (De Carlos et al.2006).
Traditional anti-inflammatory drugs are nonselective for two isoforms of cyclooxygenase, $\mathrm{COX}$ 1 and COX-2. COX-1 is related to the synthesis of prostaglandins involved in the protection mechanism of the gastric mucosa, while COX-2 is induced after the activation of inflammatory cells and participates in the synthesis of inflammation mediators (Laudanno et al. 2001). In this context, NSAIDs selective for COX-2 were developed, because COX-1 inhibition leads to gastrointestinal side effects (Bombardier et al. 2000). However, other authors affirm that COX-2 inhibition may be associated to cardiovascular and renal side effects (Sari et al. 2004, Hersh et al. 2004).

Coxibs were used in five studies of the present review (De Carlos et al. 2006, 2007, Hauber Gameiro et al. 2008, Stabile et al. 2009, Gonzales et al. 2009). Generally, these drugs showed distinct effects regarding orthodontic movement, either having negative influence on it or not interfering with it. However, celecoxib responds more frequently for tooth displacement inhibition, exerting distinct levels of interference in three studies (De Carlos et al. 2007, Hauber Gameiro et al. 2008, Stabile et al. 2009). The distinct effects obtained with the use of these drugs may be related to some factors: the half-life of the drug, the bioavailability, the form of administration, the concentration, the experimental period, and the methods of assessing tooth movement (De Carlos et al. 2006, Hauber Gameiro et al. 2008).

Acetaminophen proved to be the most effective of the drugs assessed in our review, which corroborates its pharmacological use in orthodontic movement disturbances. This drug is a widely used non-opioid and analgesic that is effective against several types of pain, but the consequences of overdose may be severe (Raffa et al. 2014). Acetaminophen works as a weak antiinflammatory (considered rather negligible for therapeutic purposes) because its lacks carboxylic acid moiety for interacting with arginine 120 
from COX-1 and COX-2 (Simmons et al. 2000). Consequently, it is also a weak inhibitor of the synthesis of prostaglandins (PGs). On the other hand, it has been suggested that acetaminophen works by inhibiting the COX-3 isoform (a COX-1 splice variant) from the COX family of enzymes, although there is still little knowledge on the true role of COX-3 in inflammation or whether the action of acetaminophen on COX-3 is relevant to its pharmacological effects (Hinson et al. 2010). Moreover, these effects against COX-3 have been meanwhile rejected because the existence of a functional human COX-3 has been questioned (Hinz et al. 2008). So, the most likely hypothesis of the anti-inflammatory effect (even if weak) of the acetaminophen remains on the fact that it works as an inhibitor of peripheral COX-1 and COX-2 enzymes (Hinz et al. 2008), which inserts this drug as a weak NSAIDs (Hinz et al. 2008).

Yet the analgesic function of acetaminophen is associated with serotonergic and opioidergic mechanisms. Acetaminophen showed connection with $\left({ }^{3} \mathrm{H}\right)$ naloxone binding sites; increased brain 5-hydroxytryptamine concentrations; and reduced number of $5 \mathrm{HT}_{2}$ receptors in cortical membranes. These effects are similar to those of morphine (Pini et al. 1997). Thus, these effects on neurotransmitter systems involved in painful awareness, as well as their ambiguous effect on COX isoforms, are key points that help to explain the clinical importance of acetaminophen for the management of pain from tooth movement during orthodontic treatment.

The present review shows that paracetamol (acetaminophen) was the only drug that presented unanimous results regarding the influence on orthodontic movement. All studies showed that this drug did not interfere within tooth movement throughout the entire experimental period (Arias and Marquez-Orozco 2006, Hauber Gameiro et al. 2008, Gonzales et al. 2009). These aspects strengthen the hypothesis that paracetamol does not exert intense activity regarding the inhibition of peripheral synthesis of prostaglandins, reducing the pain by acting along the central nervous system (Arias and Marquez-Orozco 2006). However, authors affirm that meloxicam also may not affect orthodontic movement (Gonzales et al. 2009). Considering that the outcomes of the present review were founded on scarce literature source, more studies remain necessary (especially as controlled clinical trials) to overcome this limitation and to test the influence of Paracetamol on induced tooth movement. The same is suggested for the influence of meloxicam.

The analysis of methodological aspects of the studies that assessed the interaction between NSAIDs and orthodontic movement in rats revealed a high degree of heterogeneity. Standardization is required for the type of orthodontic appliance used, anatomic region of installation, teeth involved, type of drug used, concentration, form, and respective administration period. It is known that there is a certain difference in metabolic conditions and other biological functions between animals and human beings. Thus, the development of randomized and controlled clinical tests is suggested in order to verify the extension of these results in humans. In conclusion, the present systematic review indicated that paracetamol may be considered the drug of choice for pain relief without interfering with induced tooth movement.

\section{REFERENCES}

ALHASHIMI N, FRITHIOF I, BRUDVIK P AND BAKHIET M. 2001. Orthodontic tooth movement and de novo synthesis of proinflammatory cytokines. Am J Orthod Dentofacial Orthop 119: 307-312.

ARIAS OR AND MARQUEZ-OROZCO MC. 2006. Aspirin, acetaminophen, and ibuprofen: their effects on orthodontic tooth movement. Am J Orthod Dentofacial Orthop 130: 364-370.

BOLLEN A, CRUZ JC, BAKKO DW, HUANG GJ AND HUJAEL PP. 2008. The effect of orthodontic therapy on periodontal health. A systematic review of controlled evidence. J Am Dent Assoc 139: 413-442. 
BOMBARDIER C ET AL. 2000. Comparison of upper gastrointestinal toxicity of rofecoxib and naproxen in patients with rheumatoid arthritis - VIGOR Study Group. N Engl J Med 343: 1520-1528.

CERICATO GO, BITTENCOURT MA AND PARANHOS LR. 2015. Validity of the assessment method of skeletal maturation by cervical vertebras: A systematic review and meta-analysis. Dentomaxillofac Radiol 44: 20140270.

DE CARLOS F, COBO J, DIAZ-ESNAL B, ARGUELLES J, VIJANDE M AND COSTALES M. 2006. Orthodontic tooth movement after inhibition of cyclooxygenase-2. Am J Orthod Dentofacial Orthop 129: 402-406.

DE CARLOS F, COBO J, PERILLAN C, GARCIA MA, ARGUELLES J, VIJANDE M AND COSTALES M. 2007. Orthodontic tooth movement after different coxib therapies. Eur J Orthod 29: 596-599.

FERNANDES LM, OGAARD B AND SKOGLUND L. 1998. Pain and discomfort experienced after placement of a conventional or a superelastic NiTi aligning archwire. J Orofac Orthop 59: 331-339.

GARLET TP, COELHO U, REPEKE CE, SILVA JS, CUNHA FQ AND GARLET GP. 2008. Differential expression of osteoblast and osteoclast chemo attractants in compression and tension sides during orthodontic movement. Cytokine 42: $330-335$.

GARLET TP, COELHO U, SILVA JS AND GARLET GP. 2007. Cytokine expression pattern in compression and tension sides of the periodontal ligament during orthodontic tooth movement in humans. Eur J Oral Sci 115: 355-362.

GOLTZMAN D AND HENDY GN. 2015. The calciumsensing receptor in bone--mechanistic and therapeutic insights. Nat Rev Endocrinol 11: 298-307.

GONZALES C, HOTOKEZAKA H, MATSUO K, SHIBAZAKI T, YOZGATIAN JH, DARENDELILER MA AND YOSHIDA M. 2009. Effects of steroidal and nonsteroidal drugs on tooth movement and root resorption in the rat molar. Angle Orthod 79: 715-726.

HAUBER GAMEIRO G, NOUER DF, PEREIRA NETO JS, SIQUEIRA VC, ANDRADE ED, DUARTE NOVAES P AND VEIGA MC. 2008. Effects of short- and long-term celecoxib on orthodontic tooth movement. Angle Orthod 78: 860-865.

HERSH EV, LEVIN LM, ADAMSON D, CHRISTENSEN S, KIERSCH TA, NOVECK R, WATSON 2ND G AND LYON JA. 2004. Dose-ranging analgesic study of Prosorb diclofenac potassium in postsurgical dental pain. Clin Ther 269: 1215-1227.

HINSON JA, ROBERTS DW AND JAMES LP. 2010. Mechanisms of acetaminophen-induced liver necrosis. Handb Exp Pharmacol 196: 369-405.

HINZ B, CHEREMINA O AND BRUNE K. 2008. Acetaminophen (paracetamol) is a selective cyclooxygenase-2 inhibitor in man. The FASEB Journal 22: 383-390.

KALE S, KOCADERELI I, ATILLA P AND ASAN E. 2004. Comparison of the effects of 1,25 dihydroxycholecalciferol and prostaglandin E2 on orthodontic tooth movement. Am J Orthod Dentofacial Orthop 125: 607-614.

KANZAKI H, CHIBA M, SHIMIZU Y AND MITANI H. 2002. Periodontal ligament cells under mechanical stress induce osteoclastogenesis by receptor activator of nuclear factor Kappa B ligand up-regulation via prostaglandin E2 Synthesis. J Bone Miner Res 17: 210-220.

KARTHI M, ANBUSLEVAN GJ, SENTHILKUMAR KP, TAMIZHARSI S, RAJA S AND PRABHAKAR K. 2012. NSAIDs in Orthodontics tooth movement. J Pharm Bioallied Sci 4: S304-306.

KRISHNAN V AND DAVIDOVITCH Z. 2006. Cellular, molecular, and tissue-level reactions to orthodontic force. Am J Orthod Dentofacial Orthop 129: 469.e1-32.

LAUDANNO OM, CESOLARI JA, ESNARRIAGA J, RISTA M, PIOMBO G, MAGLIONE C, ARAMBERRY L, SAMBRANO J, GODOY A AND ROCASPANA A. 2001. Gastrointestinal damage induced by celecoxib and rofecoxib in rats. Dig Dis Sci 46: 779-784.

LIBERATI A, ALTMAN DG, TETZLAF JF, MULROW C, GOTZSCHE PC, IOANNIDIS JPA, CLARKE M, DEVEREAUX PJ, KLEIJNEN J AND MOHER D. 2009. The PRISMA statement for reporting systematic reviews and meta-analyses of studies that evaluate health care interventions: explanation and elaboration. PLOS Med 6: e1000100.

LIMPANICHKUL W, GODFREY K, SRISUK N AND RATTANAYATIKUL C. 2006. Effects of low-level laser therapy on the rate of orthodontic tooth movement. Orthod Craniofac Res 9: 38-43.

MARIE SS, POWERS M AND SHERIDAN JJ. 2003. Vibratory stimulation as a method of reducing pain after orthodontic appliance adjustment. J Clin Orthod 37: 205-208.

MELSEN B. 2015. Ortodontia: Tratamento em Adultos. $1^{\mathrm{a}}$ ed., Maringá: Dental Press.

NAKASHIMA T AND TAKAYANAGI H. 2009. Osteoimmunology: crosstalk between the immune and bone systems. J Clin Immunol 29: 555-567.

O'CONNOR PJ. 2000. Patients perceptions before, during, and after orthodontic treatment. J Clin Orthod 34: 591-592.

PINI LA, VITALE G, OTTANI A AND SANDRINI M. 1997. Naloxone-reversible antinociception by paracetamol in the rat. J Pharmacol Exp Ther 280: 934-940.

RAFFA RB, PERGOLIZZI JR JV, TAYLOR JR R, DECKER JF AND PATRICK JT. 2014. Acetaminophen (paracetamol) oral absorption and clinical influences. Pain Pract 14: 668677.

REPEKE CE, FERREIRA JR SB, CLAUDINO M, SILVEIRA EM, DE ASSIS GF, AVILA-CAMPOS MJ, SILVA JS 
AND GARLET GP. 2010. Evidences of the cooperative role of the chemokines CCL3, CCL4 and CCL5 and its receptors CCR1+ and CCR5+ in RANKL+ cell migration throughout experimental periodontitis in mice. Bone 46: 1122-1130.

SARI E, OLMEZ H AND GURTON AU. 2004. Comparison of some effects of aceylsalicylic acid and Rofecoxib during orthodontic tooth movement. Am J Orthod Dentofacial Orthop 125: 310-315.

SCHEURER P, FIRESTONE A AND BURGIN W. 1996. Perception of pain as a result Abstract of orthodontic Orthodontics treatment with fixed appliances. Eur J Orthod 18: 349-357.

SEIFI M, ESLAMI B AND SAFFAR AS. 2003. The effect of prostaglandin E2 and calcium gluconate on orthodontic tooth movement and root resorption in rats. Eur J Orthod 25: 199-204.

SHETTY N, PATIL AK, GANESHKAR SV AND HEGDE S. 2013. Comparison of the effects of ibuprofen and acetaminophen on PGE2 levels in the GCF during orthodontic tooth movement: a human study. Prog Orthod 14: 6-6.
SIMMONS DL, WAGNER D AND WESTOVER K. 2000. Nonsteroidal anti-inflammatory drugs, acetaminophen, cyclooxygenase 2, and fever. Clin Infect Dis 31: S211-218.

STABILE AC, STUANI MB, LEITE-PANISSI CR AND ROCHA MJ. 2009. Effects of short-term acetaminophen and celecoxib treatment on orthodontic tooth movement and neuronal activation in rat. Brain Res Bull 79: 396-401.

TAKAYANAGI H. 2012. New developments in osteoimmunology. Nat Rev Rheumatol 8: 684-689.

WEISS DD AND CARVER DM. 1994. Transcutaneous electrical neural stimulation for pain control. J Clin Orthod 28: 670-671.

XIAOTING L, YIN T AND YANGXI C. 2010. Interventions for pain during fixed orthodontic appliance therapy. Angle Orthod 80: 925-932.

YAMAGUCHI M. 2009. RANK/RANKL/OPG during orthodontic tooth movement. Orthod Craniofac Res 12: 113-119.

YAMASAKI K, SHIBATA Y, IMAI S, TANI Y, SHIBASAKI Y AND FUKUHARA T. 1984. Clinical application of prostaglandin E1 (PGE1) upon orthodontic tooth movement. Am J Orthod 85: 508-518. 